\title{
Studi Etnografi Virtual Tentang Belajar Bisnis Untuk Ibu Rumah Tangga di Saluran Youtube Belajar Berbisnis
}

Authors : Rachmaniar

Published by : Departemen of Sociology, Faculty of Social and Political Science, Universitas Padjadjaran

Accepted : May 2017; Approved : June 2017

Sosiogobal: Jurnal Pemikiran dan Penelitian Sosiologi is the Department of Sociology, Faculty of Social and Political Science, Universitas Padjadjaran flagship journal. The Sosioglobal journal founded in 2016 with the mission to publish original works of interest to the discipline of sociology in general, sociological thinking, new theoretical developments, results of research that enhance understanding of fundamental social processes, and methodological innovations. We are welcome a research article, working paper, theoretical/conceptual and methodological review to submit to our journal. In addition, we are accept relevant book review that currently publish and enrich sociological perspectives. Please submit article to http://jurnal.unpad.ac.id/sosioglobal

To cite this article :

Rachmaniar.2017.Studi Etnografi Virtual Tentang Belajar Bisnis Untuk Ibu Rumah Tangga di Saluran Youtube Belajar Berbisnis.Sosioglobal : Jurnal Pemikiran dan Penelitian Sosiologi 1(2):168-174. 


\title{
STUDI ETNOGRAFI VIRTUAL TENTANG BELAJAR BISNIS UNTUK IBU RUMAH TANGGA DI SALURAN YOUTUBE BELAJAR BERBISNIS
}

\author{
Rachmaniar ${ }^{1}$ \\ 1. Prodi Ilmu Komunikasi, Fakultas Ilmu Komunikasi, Universitas Padjadjaran \\ rachmaniar@unpad.ac.id
}

\begin{abstract}
ABSTRAK
Sekarang, jika seseorang membutuhkan info tentang sesuatu, orang tersebut akan mencarinya melalui YouTube. Salah satu video yang memberikan informasi yang dibutuhkan seorang ibu rumah tangga yang terkait dengan peluang bisnis adalah 7 Peluang Usaha Rumahan yang cocok untuk Ibu Rumah Tangga di saluran YouTube Belajar Berbisnis. Video ini memiliki lebih dari 200 ribu tampilan. Berdasarkan fakta tersebut, penulis tertarik untuk menganalisis komentar netizen yang terkait dengan video bisnis tersebut. Untuk menjawab pertanyaan tersebut, penulis menggunakan teori uses and gratification dengan tradisi penelitian etnografi virtual. Hasil yang ditemukan oleh penulis adalah banyak ibu rumah tangga yang ingin belajar bisnis, yang ingin memiliki bisnis rumahan, namun mereka memiliki ketakutan gagal dalam berbisnis, bingung berbisnis, dan tetap menganggap modal sebagai salah satu faktor penentu kesuksesan berbisnis. Komentar netizen terkait dengan video 7 Peluang Usaha Rumahan yang cocok untuk Ibu Rumah Tangga di saluran YouTube Belajar Berbisnis: banyak netizen yang memberikan komentar positif mengenai video tersebut, 2) Ada netizen yang memberikan komentar negatif mengenai video tersebut, dan 3) Ada netizens yang mengungkapkan beberapa pertanyaan terkait video yang diupload.
\end{abstract}

Kata kunci: belajar bisnis, ibu rumah tangga, youtube

\begin{abstract}
Now, if someone needs info aboutsomething, the person will search it through YouTube. One of the videos that provide the information a person needs - a housewife related to a business opportunity is 7 Peluang Usaha Rumahan yang cocok untuk Ibu Rumah Tangga on the YouTube channel Belajar Berbisnis. This video has over 200 thousand views. Based on that fact, the authors became interested in analyzing the netizen comments related to that business video. To answer these questions, the authors use uses and gratification theory with virtual ethnographic research tradition. The results found by the author are many housewives who want to learn business, who want to have a home business, but they have fears of failing in business, confused business, and still consider capital as one of the determining factors the success of doing business. The netizen comments related to the videos 7 Peluang Usaha Rumahan yang cocok untuk Ibu Rumah Tangga on the YouTube channel Belajar Berbisnis: many netizens who gave positive remarks concerning the video, 2) There are netizens who give negative comments concerning the video, and 3) there are netizens who express some questions related to the uploaded video.
\end{abstract}

Keywords : learn business, housewife, youtube 


\section{PENDAHULUAN}

Lembaga riset pasar e-Marketer mengungkap bahwa jumlah pengguna internet di Indonesia menembus angka 83,7 juta di tahun 2014. Angka tersebut memiliki arti setidaknya setiap sebulan sekali setiap orang Indonesia mengakses internet. eMarketer memprediksi bahwa pengguna internet di Indonesia akan menembuas angka 112 juta di tahun $2017 .{ }^{1}$

\begin{tabular}{|c|c|c|c|c|c|c|}
\hline & 2013 & 2014 & 2015 & 2016 & 2017 & 2018 \\
\hline 1. China* & 6207 & 6436 & 6698 & 700.1 & 738.2 & 770 \\
\hline 2. US" & 246.0 & 2529 & 259.3 & 264.9 & 269.7 & 274.1 \\
\hline 3. Inda & 167.2 & 215.6 & 2523 & 283.8 & 3138 & 346.3 \\
\hline 4. Brazl & $\infty 2$ & 107.7 & 1137 & 119.8 & 123.3 & 125.9 \\
\hline 5. Japan & 1000 & 102.1 & 1036 & 1045 & 105.0 & 105.4 \\
\hline 6. Indonesia & 72.8 & 83.7 & 93.4 & 102.8 & 112.6 & 123.0 \\
\hline 7. Russia & 77.5 & 82.9 & 873 & 91.4 & 943 & 96.6 \\
\hline 8. Germany & 59.5 & 61.6 & 622 & 62.5 & 627 & 62.7 \\
\hline 9. Mexoco & 53.1 & 59.4 & 65.1 & 70.7 & 75.7 & 80.4 \\
\hline 10. Nigeria & 51.8 & 57.7 & 632 & 69.1 & 76.2 & 84.3 \\
\hline 11, UK $\cdots$ & 48,8 & 50.1 & 513 & $\$ 24$ & 53.4 & 543 \\
\hline 12. France & 48.8 & 497 & 50.5 & 51.2 & 51.9 & 525 \\
\hline 13. Philippines & 423 & 480 & $\$ 3.7$ & 59.1 & 64.5 & 69.3 \\
\hline
\end{tabular}

\begin{tabular}{|c|c|c|c|c|c|c|}
\hline 14. Turkey & 36.6 & 410 & 447 & 47.7 & 507 & 53.5 \\
\hline 15. Vietnam & 36.6 & 40.5 & 444 & 48.2 & 52.1 & 558 \\
\hline 16. South Korea & 40.1 & 40.4 & 40.6 & 40.7 & 40.9 & 41.0 \\
\hline 17. Esypt & 34,1 & 36.0 & 383 & 40.9 & 43.9 & 47.4 \\
\hline 18. raly & 34.5 & 35.8 & 362 & 37.2 & 37.5 & 37.7 \\
\hline 19. Spain & 30.5 & 316 & 323 & 330 & 33.5 & 33.9 \\
\hline 20. Canada & 27.7 & 28.3 & 28.8 & 29.4 & 29.9 & 30.4 \\
\hline 21. Argentina & 250 & 27.1 & 290 & 29.8 & 30.5 & 31.1 \\
\hline 22 Colombia & 242 & 26.5 & 28.6 & 20.4 & 30.5 & 31.3 \\
\hline 23. Thsiland & 227 & 243 & 260 & 27.6 & 29.1 & 30.6 \\
\hline 24. Poland & 226 & 22.9 & 233 & 23.7 & 24.0 & 24.3 \\
\hline 25. South Africa & 20.1 & 227 & 250 & 27.2 & 292 & 30.9 \\
\hline Woridwide*.. & 2.692 .9 & 2.892 .7 & $3,072.6$ & $3,246.3$ & 3.419 .9 & $3,600.2$ \\
\hline \multicolumn{7}{|c|}{ 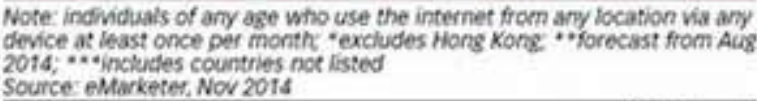 } \\
\hline
\end{tabular}

Fakta tersebut salah satunya dapat terlihat dari meningkatnya jumlah penonton YouTube dan berkurangnya jumlah penonton televisi. Berdasar hasil penelitian firma Mildward Brown diketahui bahwa 30 persen jumlah orang yang ada di Indonesia, 52 persen orang menyaksikan video melalui internet - perilaku pemilik smartphone di Indonesia lebih memilih menyaksikan video melalui internet daripada menyaksikan tayangan melalui televisi

Orang Indonesia kini lebih banyak nonton video di internet ketimbang nonton tayangan di televisi. Hal tersebut terungkap dari hasil penelitian firma Millward Brown tentang perilaku pemilik smartphone di Indonesia. Lebih spesifiknya, dari 30 persen populasi di Indonesia, 52 persen di antaranya menonton video di internet, salah satunya YouTube, melalui smartphone, tablet, atau laptop. ${ }^{2}$

Pihak YouTube sendiri menyatakan bahwa jumlah orang yang menyaksikan YouTube lebih besar jumlahnya daripada jumlah orang yang menyaksikan televise.

\footnotetext{
${ }^{1}$ Kementerian Komunikasi dan Informatika Republik Indonesia. (2014). Pengguna Internet Indonesia Nomor Enam Dunia. Diakses pada 23 Agustus 2016, dari https://kominfo.go.id/content/detail/4286/penggunainternet-indonesia-nomor-enam-dunia/0/sorotan_media

2 Bohang, Fatimah Kartini. (2015). TV Ditinggalkan, Ini Tontonan Favorit Baru Orang Indonesia. Diakses pada 23 Agustus 2016, dari http://tekno.kompas.com/read/2015/11/25/12310007/

TV.Ditinggalkan.Ini.Tontonan.Favorit.Baru.Orang.Indonesia
} 


\section{RACHMANIAR}

Pihak YouTube menyatakan bahwa Interpublic Group, yang menjadi salah satu perusahaan pembuat iklan paling besar di dunia, berniat mengalihkan budget sebanyak 250 juta dollar Amerika yang awalnya untuk iklan di televisi menjadi untuk iklan di YouTube. ${ }^{3}$

Fakta ini menyiratkan bahwa keberadaan YouTube menjadi media yang dipilih oleh khalayak. Tidak mengherankan, jika seseorang membutuhkan info yang berkaitan dengan sesuatu hal, orang tersebut akan mencari salah satunya melalui media sosial YouTube. Salah satu video yang memberikan informasi yang dibutuhkan seseorang - seorang ibu rumah tangga yang terkait dengan peluang bisnis adalah 7 Peluang Usaha Rumahan yang cocok untuk Ibu Rumah Tangga di saluran YouTube Belajar Berbisnis. Video ini memiliki lebih dari 200 ribu tampilan. Berdasarkan fakta tersebut, keberadaan video belajar bisnis di saluran YouTube, penulis tertarik untuk menganalisis komentar netizen terkait video tersebut dilihat dari komentar positif, komentar negatif, dan pertanyaan tentang video 7 Peluang Usaha Rumahan. Yang cocok untuk Ibu Rumah Tangga di saluran YouTube Belajar Berbisnis. Untuk menjawab pertanyaan tersebut, penulis menggunakan tradisi penelitian etnografi virtual, dengan teori uses and gratification.

\section{METODE PENELITIAN}

Penelitian ini menggunakan etnografi virtual yaitu metode etnografi yang berupaya untuk memotret fenomena di masyarakat serta budaya para netizen di dunia maya (Nasrullah, 2014: 171). Etnografi virtual mempersoalkan dugaan yang telah yang telah ada pada orang banyak mengenai internet, menafsirkan juga menafsir ulang internet sebagai suatu metode juga media yang dipakai dalam berkomunikasi, adalah "ethnography in, of and trough the virtual" - hubungan secara bertemu muka atau face to face tidak dibutuhkan (Hine, 2001).

Tom Boellstorff, professor di bidang antropologi University of California, US menyatakan bahwa penelitian etnografi virtual, pada dasarnya memiliki prinsip-prinsip yang sama dengan penelitian etnografi, dimana runtutan untuk menjalankan dan mendirikan etnografi memakai wilayah virtual online untuk lokasi penelitiannya.

Boellstorf menyatakan bahwa untuk mengumpulkan data penelitian yang tidak menggunakan wilayah (dunia virtual) artinya dianggap sebagai sebuah pelanggaran "in their own term", karena setiap hal harus diketahui mempunyai makna dalam konteksnya masing-masing.

\footnotetext{
3 Amalia, Ellavie Ichlasa. (2016). Bos YouTube: Penonton TV Berkurang, Penonton Kami Bertambah. Diakses pada 23 Agustus 2016, dari http://teknologi.metrotvnews.com/news-teknologi/Obz9BJeN-bos-YouTube-penonton-tvberkurang-penonton-kami-bertambah
}

170 | SGSIOGLLBAL Jurnal Pemikiran dan Penelitian Sasiologi, Vol. I, №. 2, Juni 2017 
Dalam etnografi virtual, wawancara dan survei bisa dirubah melalui koleksi/ arsip yang telah dimiliki yang sumbernya dari info-info yang beredar di wilayah online contohnya situs jejaring social dan forum internet. Info-info tersebut selanjutnya bisa dijumpai dan dikumpulkan dari internet tanpa lagi harus ditulis dan dicatat seperti etnografer tradisional (Evans, 2010:2).

Karena penelitian ini bertujuan untuk menganalisis komentar netizen terkait video belajar berbisnis di saluran Youtube, maka data dikumpulkan dengan membaca setiap komentar yang diposting oleh netizen sejak video diunggah pada 4 Februari 2016. Ada 106 komentar di kolom komentar dari video yang dibahas. Setiap komentar dan balasan dari komentar diarsipkan, dibaca, dan ditelaah dengan mendalam untuk melihat bagaimana komentar netizen terkait video belajar berbisnis di saluran YouTube.

\section{KERANGKA TEORI/KONSEP}

Teori yang digunakan adalah teori uses and gratification. Dalam teori ini tidak lagi melihat pengaruh media pada khalayak, namun apa yang dilakukan khalayak ke media. ${ }^{4}$ Teori ini menyatakan bahwa pengguna media memiliki peran aktif dalam menggunakan serta memilih media tertentu. Artinya, pengguna media menjadi orang yang memiliki otoritas dalam proses komunikasi.. Pengguna media berupaya dalam menemukan sumber media yang paling sesuai untuk memuaskan kebutuhannya. Dengan demikian, pada teori uses and gratifications diperkirakan pengguna memiliki alternative pilihan dalam memuaskan kebutuhannya (Effendy, 2002: 289-290).

Teori uses and gratifications menekankan khalayak adalah orang yang aktif untuk menentukan media yang akan dipilihnya dalam memuaskan kebutuhannya. Teori ini lebih mengutamakan pendekatan manusiawi ketika melihat media. Manusia dianggap memiliki hak atau kekuasaan dalam berhubungan dengan media. Blumer dan Katz meyakini ada banyak faktor bagi audience dalam memilih media, bukan hanya satu faktor saja bagi audience untuk memilih media. $^{5}$

Masalah terpenting pada teori uses and gratifications tidak pada keberadaan media yang mengubah audience dalam sikap dan perilaku, tetapi pada keberadaan media yang memiliki kemampuan untuk memuaskan kebutuhan pribadi serta social audiencenya. Intinya teori ini berbicara tentang kehadiran audience yang aktif, yang dengan kesadarannya memilih media tertentu dalam rangka mendaatkan tujuan tertentu (Effendy, 2002: 289-290).

\footnotetext{
${ }^{4}$ Fajrie, Mahfudlah. (2015). Analisis Uses and Gratification dalam Menentukan Strategi Dakwah. Journal Islamic Review, Vol 4, No 1

${ }^{5}$ Ibid
} 


\section{RACHMANIAR}

Teori uses and gratification diilustrasikan dengan a dramatic break with tradition of the past, sebuah lompatan luar biasa sejak lahirnya model jarum hipodermik, teori ini bukan berfokus dengan apa yang diperbuat media kepada khalayak, namun berfokus kepada apa yang diperbuat khalayak kepada media. Para audience dinilai sebagai orang yang berperan memilih media untuk memuaskan kebutuhannya. Penggunaan media menjadi salah satu hal untuk memuaskan kebutuhan psikologis, sementara efek media dinilai menjadi sebuah keadaan ketika kebutuhan tersebut terpuaskan. (Rakhmat, 2005: 65).

\section{PEMBAHASAN}

Berdasarkan video 7 Peluang Usaha Rumahan yang cocok untuk Ibu Rumah Tangga di saluran YouTube Belajar Berbisnis, ada beberapa hal yang bisa didiskusikan:

\section{Komentar positif}

Banyak netizen menyatakan bahwa video itu bagus, menarik, dan mudah dimengerti. Selanjutnya banyak netizens menyatakan bahwa video tersebut sangat bermanfaat, menginspirasi, dan video dapat membantu netizens semakin bersemangat dan termotivasi untuk mencoba berbisnis. Akhirnya, banyak netizens mengucapkan terima kasih, pujian, dan memberi salam sukses bagi pemilik saluran youtube.

Intinya netizens merasa puas dengan video yang diupload. Ada banyak hal positif tentang video sehingga kolom komentar dipenuhi dengan ucapan positif. Isi video terstruktur dan detail membuat netizen sangat mengerti dengan konten video yang diupload. Selain itu pemilik saluran YouTube menyediakan informasi yang berkaitan dengan pembuatan produk, di mana memasarkan produk, kisaran harga produk, cara mempromosikan produk, omset, hingga peluang bisnis. Semua konten membuat kolom komentar penuh dengan ucapan positif.

\section{Komentar negatif}

Ada netizen yang memberikan komentar negatif terkait video tersebut. Tidak peduli seberapa bagus sebuah video, saat ditonton oleh ribuan netizens, masih akan ada komentar negatif yang muncul di kolom komentar. Dan sebenarnya komentar yang disampaikan bukanlah komentar negatif, namun cara mereka menyampaikannya membuat komentar tersebut terkesan memiliki kesan negatif.

Ketika netizens menyampaikan dengan sopan dan halus, dan menggunakan bahasa etis, orang akan menganggapnya sebagai komentar yang membangun - saran dan umpan balik. Tapi ketika mereka menyampaikannya dengan cara yang salah, komentar tersebut akan dianggap sebagai komentar ofensif, sebuah komentar negatif. 
Komentar negatif yang disampaikan oleh netizens terkait dengan video tersebut adalah komentar yang berkaitan dengan bisnis bukanlah sesuatu yang unik (banyak orang sudah menjalankan bisnis itu), dan ada kekhawatiran dari netizens yang gagal melakukan bisnis. Bila dilihat dari isi komentar, sebenarnya sangat membangun, hanya karena cara menyampaikannya yang sedikit buruk dan tidak menggunakan bahasa yang sesuai, komentar tersebut sepertinya memiliki kesan negatif. Salah satu contoh komentar negatif dari video tersebut adalah konten dalam video terlalu rumit untuk dijalankan, tidak pasti, lebih baik memanfaatkan investasi yang ada. Investasi dianggap lebih mudah dan menguntungkan.

\section{Pertanyaan}

Ada netizens yang mengungkapkan beberapa pertanyaan terkait video yang diupload. Meski dalam video ini ada komentar negatif, harus diakui bahwa jumlah komentar positif paling banyak, dan ada juga yang berisi pertanyaan.

Untuk komentar berisi pertanyaan, terdiri dari: 1) netizens sangat bingung untuk memulai bisnis, 2) netizens bingung memilih bisnis yang sesuai untuknya, 3) netizens merasa mereka tidak memiliki kemampuan dan modal yang cukup untuk menjalankan bisnis. Untuk masalah ini, netizens bertanya kepada pemilik saluran YouTube. Intinya netizens punya keinginan, tapi punya kegelisahan, dan bertanya bagaimana menghadapi masalah itu agar bisa sukses dalam menjalankannya.

\section{Temuan}

- Banyak ibu rumah tangga yang ingin belajar bisnis, yang ingin memiliki bisnis rumahan, namun mereka memiliki ketakutan gagal dalam berbisnis, bingung berbisnis, dan tetap menganggap modal sebagai salah satu faktor penentu keberhasilan berbisnis.

- Bila sesuatu memiliki judul yang mudah dimengerti, konten bagus, dan pengiriman pesan detail, netizens cenderung menyukai video yang diunggah dan mereka akan menghargainya dengan komentar positif dan ucapan terima kasih.

- Tidak peduli seberapa bagus sebuah video, saat ditonton oleh ribuan netizens, masih akan ada komentar negatif yang muncul di kolom komentar. Dan sebenarnya komentar yang disampaikan bukanlah komentar negatif, namun cara mereka menyampaikannya membuat komentar tersebut terkesan memiliki kesan negatif. 


\section{SIMPULAN}

Komentar netizen terkait dengan video 7 Peluang Usaha Rumahan yang cocok untuk Ibu

Rumah Tangga di saluran YouTube Belajar Berbisnis:

a. Banyak netizen yang memberikan komentar positif mengenai video tersebut, 2) ada netizen yang memberikan komentar negatif mengenai video tersebut, dan 3) ada netizens yang mengungkapkan beberapa pertanyaan terkait video yang diupload.

b. Banyak ibu rumah tangga yang ingin belajar bisnis, yang ingin memiliki bisnis rumahan, namun mereka memiliki ketakutan gagal dalam berbisnis, bingung berbisnis, dan tetap menganggap modal sebagai salah satu faktor penentu keberhasilan berbisnis.

\section{DAFTAR PUSTAKA}

Amalia, Ellavie Ichlasa. (2016). Bos YouTube: Penonton TV Berkurang, Penonton Kami Bertambah. Diakses pada 23 Agustus 2016, dari http://teknologi.metrotvnews.com/news-teknologi/Obz9BJeN-bos-YouTubepenonton-tv-berkurang-penonton-kami-bertambah

Boellstorff, Tom. 2008. Coming of Age in Second Life : An Anthropologist Explores The Virtually Human. New Jersey: Princenton University Press.

Bohang, Fatimah Kartini. (2015). TV Ditinggalkan, Ini Tontonan Favorit Baru Orang Indonesia. Diakses pada 23 Agustus 2016, dari http://tekno.kompas.com/read/2015/11/25/12310007/TV.Ditinggalkan.Ini.Tontonan. Favorit.Baru.Orang.Indonesia

Effendy, Onong Uchjana. 2002. Ilmu Komunikasi Teori dan Praktek. Bandung: PT. Remaja Rosdakarya.

Fajrie, Mahfudlah. (2015). Analisis Uses and Gratification dalam Menentukan Strategi Dakwah. Journal Islamic Review, Vol 4, No 1

Hine, Christine. 2001. Virtual Ethnography. London: Sage Publication Ltd.

Kementerian Komunikasi dan Informatika Republik Indonesia. (2014). Pengguna Internet Indonesia Nomor Enam Dunia. Diakses pada 23 Agustus 2016, dari https://kominfo.go.id/content/detail/4286/pengguna-internet-indonesia-nomor-enamdunia/0/sorotan_media

Nasrullah, Rulli. 2014. Teori dan Riset Media Siber (Cybermedia). Jakarta: Kencana.

Rakhmat, Jalaluddin. 2005. Psikologi Komunikasi. Bandung: Remaja Rosdakarya. 